\title{
EU CRISIS AND CONSTITUTIONAL MUTATIONS: A REVIEW ARTICLE
}

\author{
GIUSEPPE MARTINICO $(*)$ \\ Centro de Estudios Políticos y Constitucionales, Madrid \\ Scuola Superiore Sant'Anna, Pisa
}

I. Financial Crisis, EU Crisis and Constitutional Implications.II. The Background in a nutshell.- - III. The New Economic Governance: Asymmetry and Intergovernmentalism.-IV. What Can We Learn From the National Level?--V. Bibliography.

\section{RESUMEN}

El objetivo de este artículo es ofrecer una panorámica de la literatura más relevante sobre las implicaciones constitucionales derivadas de la crisis de la Unión europea (UE). Mi análisis explora las principales opiniones doctrinales sobre las mutaciones de la estructura constitucional de la Unión producidas por la crisis. Con este propósito el término «mutación constitucional» no debe entenderse como una completa ruptura con el pasado y de hecho a lo largo de este artículo trataré de enfatizar en ambas, ya sea la continuidad o la discontinuidad, en relación con la concepción tradicional del proceso de constitucionalización de la UE.

Palabras claves: Unión europea, crisis, gobernanza económica europea, intergubernamentalismo, asimetría, derecho constitucional europeo.

(*) Many Thanks to Giuseppe Bianco, Giacomo Delledonne, Mario Kölling and Anna Margherita Russo for their help. Article completed on 1 November 2013. 


\section{ABSTRACT}

The aim of this article is to offer an overview of the relevant literature devoted to the constitutional implications of the European Union (EU) crisis. My analysis explores the main scholarly views on the mutations of the constitutional structure of the Union produced by the crisis. To this purpose I do not conceive «constitutional mutation» as a complete rupture from the past and in fact in this piece I shall try to stress both continuities and discontinuities with the traditional understanding of the EU constitutionalization process.

Key words: European Union; Crisis; European Economic Governance; Intergovernmentalism; Asymmetry; European Constitutional Law.

\section{Financial Crisis, EU Crisis and Constitutional Implications}

The aim of this article is to offer an overview of the relevant literature devoted to the constitutional implications of the European Union (EU) crisis. I shall not necessarily limit myself to legal literature but articles from other disciplines will also be taken into account for the purpose of this work. This responds to the very multidisciplinary debate(1) on crisis and can be connected to the fact that «the European Union is not undergoing one crisis, but is instead suffering several simultaneous, interrelated, and intertwined crises-crises, which are global, not exclusively European. Put differently, the subprime crisis turned the economic, financial, fiscal, macroeconomic, and political structure weaknesses of the Western socio-economic order into at least five major crises» (2).

However, my approach is that of a lawyer interested in presenting the main scholarly views on the mutations of the constitutional structure of the Union (3) produced by these events (4).

(1) Habermas (2012); Athanassiou, (2011); Borger (2013); Buzelay, (2009); Chaltiel (2011); Maduro, Kumm and de Witte (2012); Chemain (2012); Hinarejos (2012); Hoffmann (2012); Louis (2012); Solddatos (2012); Bogrdandy - GoldmanN (2013); OFFE (2013).

(2) Menéndez, (2012) p. 453. See also: Dehousse (2012) and Tuori (2012).

(3) For this concept see: JELLINEK (I906) and IPSEN (1972), p. 58. Relying on this idea Pernice (1998) recalled that «It was very early that the German Constitutional Court recognised the mere fact, that although no explicit textual changes are made in the Constitution, the progress of European integration implies substantial «material' modifications of the contents of the Constitution, a phenomenon which Hans Peter Ipsen has called «constitutional mutation'. Those are the implications of art. 24 I GG, which allows the transfer of the sovereignty by simple legislative act, and of the general acceptance of the autonomy and supremacy of community law even over the Constitution».

(4) In this sense this article does not aim at offering solutions to the present crises. 
Indeed, the impression one gains from the current scenario is that of an EU which is currently struggling with its own constitutional limits, putting pressure on national institutions and actors [the Greek(5) and Italian cases are emblematic from this point of view]. This does not seem consistent with those celebrated theories [constitutional pluralism(6) for example] that recognise a constitutional function to the EU developed in accordance and in synergy with the national level. Moreover as comparative law shows (7), crises have always played a key role in reshaping the relationship between centre and periphery in regional, federal or quasi-federal contexts: if this is true in this case as well, the current crisis is at the same time a chance and a threat to the constitutional mission of the EU, a crisis (from Greek кpio $\iota \varsigma$, judgment, decision, election, choice) in the deepest etymological sense of the word, as it implies an important moment of reflection over the very nature of the whole integration process. Since this is not an article on the notion and the idea of the European Constitution, I shall limit myself to referring to that group of theories which, grosso modo, conceives the European Constitution as the outcome of the never ending interaction between the national and supranational levels (or poles according to other terminologies), a constitution understood as a process rather than a given document and that can be defined as «the set of EU norms, rules and principles constituting the polity and its legal order, establishing the institutions, attributing competences to the EU and dividing them among its institutions, governing the relationship between the EU and its Member States, limiting the exercise of its competences and guaranteeing the rights of the individuals governed under it» (8).

For the sake of clarity, before moving to the substance of the article it is necessary to make a few preliminary remarks. A first caveat is given by the nature itself of an article like this: since scholars have extensively written about this subject, I shall approach it by identifying some core themes that have a constitutional relevance or that have led to a potential or effective constitutional impact of the EU. This inevitably results in a kind of academic «cherry picking exercise» where the choice of the core themes maybe influenced by contingent factors (previous studies of the present author, familiarity with certain subjects, linguistic limitations etc): I am totally aware of these risks but I shall also try to give a map of some trends and tendencies present in the debate.

Another caveat concerning the selection of the sources: I have been asked to focus my attention on non-Spanish literature and I tried to do this

(5) LiNDSETH (2012).

(6) Poiares Maduro (2003).

(7) See Wallis, OAtes, (1998), p. 156. Loubert (2012).

(8) Claes ( 2011. 
by limiting the references to the Spanish contributions as far as possible with very few exceptions. Basically I initially relied on writings in English and then tried to find commonalities and differences in the debate also present in other languages (Italian, French and German); this gave me an account of the incredible diversity of approaches to the issue of the EU crisis. This variety sometimes reflects the priorities of the political agenda in a given country or the debate in the newspapers: it is not a coincidence, for instance, that in Germany subjects like the Fiscal Union or the «debt-brake» (9) are at the heart of the constitutional debate while in countries like Portugal, Italy, Greece and Spain the same question has not received the same attention by scholars of constitutional or public law. In this second group of countries constitutional lawyers have been more interested in the impact of the anti-crisis measures on the sustainability of the welfare system, on the protection of social rights and on the effect of such measures on the relationship between centre and periphery [a topic of course present only in those EU countries that have a decentralised system: they are not the majority in the Union as Gamper pointed out (10)]. Also, the constitutional traditions of these countries matter: while French scholars seem to be obsessed with the theme of the erosion of parliamentary sovereignty caused by the surveillance mechanism set up by the new European economic governance (11), the same issue is treated with different nuances in Italy and Spain, for example, where the concern about the loss of parliamentary sovereignty is undoubtedly conceived as a disturbing element per se but becomes a real danger when implying the decrease of the protection of some of the fundamental rights codified in the constitutions (mainly economic and social rights). In the latter case scholars perceive that this loss of sovereignty might affect certain policies that are at the heart of the constitutional pact and this explains why, when dealing with this question, even scholars that do not have an economic background inevitably enter the debate about the neutrality of the supranational agenda in terms of equilibrium between austerity and growth. In other words, while the French literature seems to be more interested in the institutional issue stemming from the establishment of a supranational surveillance mechanism, in other countries the focus is more on the axiological implications of this erosion of power. This can also be explained, as Delledonne pointed out(12), by the fact that in the last ten years there has been a kind of re-parliamentarisation of the loi

(9) Kube (2012); Truger - Will (2012). For an account of the debate in Germany see: GUÉROT, (2012).

(10). Gamper, (2005); SKoutaris (2012).

(11) Oliva (2012); Tusseau (2012).

(12) Delledonne (2011). 
de finances (13). Of course this does not exclude the possibility of detecting some common tendencies and indeed I will try to privilege them in my analysis. Finally, mutation is not understood as completely ruptured, this means that when analysing the constitutional implications of the crisis one could find both continuities and discontinuities with the traditional understanding of the EU constitutionalisation process.

Except otherwise stated, the content of this article is based on the situation as of November 2013

\section{The BACKground IN A NUTSHell}

There is no need to recall all the debate on the genesis of the crisis(14), the literature on this is huge and the facts are very well known, in this section I will instead look at how scholars interested in EU constitutional law have interpreted the series of events which has put the EU in troubled waters.

As Maduro pointed out, it is possible to identify two different «narratives» of the economic crisis: those who accuse the EU of having major responsibility for the crisis (15) and those who blame Member States. The second group seems to insist more on the role of the States whose irresponsible fiscal policies would have amplified the crisis (16). According to the first group, instead, the fault of the EU would consist of not having been able to correct some flaws present in the European economic architecture since 1992 (the year of the Maastricht Treaty). This economic architecture has been conceived as based on four main pillars: 1) coordination of economic policy-making between Member States; 2) coordination of fiscal policies, notably through limits on government debt and deficit; 3 ) a centralised monetary policy with

(13) See Carcassonne (2007); Rousseau (2010).

(14) From a legal point of view see: Contiades (2013) and LASTRA-Louis (2013). For a comprehensive literature on financial crisis see the dossier prepared by the HAGUE ACADEMY OF INTERNATIONAL LAW (2013).

(15) Among others MenÉNDEZ (2013): «The European Union is not only experiencing these crises, but is significantly responsible for the crises in the first place. The transformation of the institutional structure of the Union and the substantive policy choices made in the last three decades have fostered the very structural weaknesses that were turned into crises by the subprime crisis. In particular, it seems to me that the self-standing and disembedded understanding of economic freedoms, as expressions of the right to individualistic private autonomy and the creation of an asymmetric economic and monetary union, played a major role in destabilizing the Union.».

(16) On these two narrative see: Poiares Maduro (2012). 
a European Central Bank (ECB) (17) and 4) the creation of a single currency (euro)(18). Especially the persistent asymmetry between the monetary union (centralised) and the economic union (based on a mere coordination of national economic policies), the incomplete (if compared to a fully-fledged federal Central Bank) mandate of the European Central Bank(19), the limited budget of the EU and the uncertainty surrounding budgetary policies in the Union together with the weaknesses of the Stability and Growth Pact (20) have been indicated among the main anomalies of the system(21). All these defects emerged with the explosion of the Greek crisis (22) which induced the EU to find a situation in order to keep Greece within the euro. The Greek crisis triggered an escalation of measures that begun with a Council Decision dated 10 May 2013 (23) and was then followed by a series of more structured but still incremental interventions (24). The apex of this series of measures has been given by the Treaty on Stability, Coordination and Governance in the Economic and Monetary Union - TSCG(25) signed by 25 European leaders at the beginning of March 2012. This Treaty represents just one of the links of a longer chain of measures adopted to fight the EU crisis (I am referring to the creation of the European Financial Stability Facility [EFSF], European Financial Stabilisation Mechanism, [EFSM], the Euro Plus Pact, the amendment of art. 136 of the TFEU, the European Stability Mechanism, [ESM], the so-called six and two packs (26) among others (27). With all these measures the EU has intended to deal with very different aspects of the crisis

(17) On the role of the ECB in the crisis see: Doely, (2013); Doherty - Lenihan (2005); BUITER- RAHBARI (2012).

(18) Degryse (2012).

(19) On the asymmetry between the economic and monetary policies see: DRAGHI (2012). See also the new interesting perspectives offered by the so called Banking Union: Council Regulation (EU) No 1024/2013 of 15 October 2013 «conferring specific tasks on the European Central Bank concerning policies relating to the prudential supervision of credit institutions».

(20) On these see Louis (2006).

(21) See now Krugman (20I2), especially chapter 10.

(22) Louis, (2010); Hofmeister (2011); Katsikas, (2012).

(23) Council Decision (2010/320/EU) of 10 May 2010.

(24) Ruffert (2011); Paliouras, (2011).

(25) Peers (2012a); Besselink- Reestman (2012); Craig (2012a); Louis (2012) House of Commons European Scrutiny Committee (2012). Pernice (2012); Tuori (2012).

(26) The so-called six pack is composed of five Regulations (Regulations n. 1173/2011, n. 1174/2011, 1175/2011, 1176/2011 and 1177/2011) and one Directive (Directive n. 2011/85). The two pack is composed of the following regulations: Regulation n. 472/2013 and 473/2013; Kocharov (2012).

(27) On this «jungle» of measures see: BIANCO (2012). 
trying to achieve a new integrated surveillance system for budgetary and economic policies and a new budgetary timeline. It insists on the establishment of clearer rules and of better coordination of national policies. This system has been provided with swifter sanctions. All these measures run in parallel. Some of them are part of the EU law legal order (six pack, two pack), some of them external to it, some of them are interdependent (in some aspects the six pack and the TSCG), some of them are not (for instance, quite roughly, while the Euro Plus Pact is more about competiveness, the TSCG is more about austerity). This explains why some Member States participate in some of these actions without necessarily being part of the others.

The contents of all these measures have been extensively analysed by scholars (28) and the aim of the next section is not to offer a mere description of them. Rather, I shall explore some common elements emerging from this scenario, namely, the asymmetrical dimension of the new European economic governance and its intergovernmental turn which induced scholars to describe the latest developments in terms of loss of supranationalism. It is interesting to notice that among the EU anti-crisis measures that which obtained more attention by constitutional lawyers have been undoubtedly the TSCG, probably because of its art. 3 which establishes a sort of forced constitutionalization of the so called «golden rule» and which triggered a series of constitutional or super-primary reforms at national level(29). The TSCG was the solution chosen to challenge the crisis after having evaluated a list of alternatives, first of all the revision of the EU Treaties, i.e. the Treaty on the Functioning of the EU (TFEU) and the Treaty on the European Union (TEU). Another option considered was the use of the enhanced cooperation as regulated under the EU Treaties. This is not an exhaustive list; authors like Beukers, (30) for instance, identified a more complex scenario but these two options are still topical, partly at least, as the last provisions of the TSCG seem to confirm.

The first option (reform of the EU Treaties) would be very risky: it would imply another round of constitutional politics and seems to be unworkable now due to the UK veto(31).

However, the possibility of reforming the EU Treaties should not be underestimated. In fact, the EU institutions might have an interest in bringing the discipline of Euro-governance fully into the Treaties in the near future,

(28) See for instance the contributions included in DE WitTE- Heritier- Trechsel, (2013). See also the first comments on the Pringle case of the CJEU: (Case C-370/12 Pringle, not yet reported); Craig (2013a); De Witte- Beukers, (2013); Кокott (2013).

(29) FABBRini (2013a).

(30) BeuKers (2013).

(31) On this see: GoRdon (2014). 
and there are several think-tanks that are currently proposing something along these lines (32).

The advantages of enhanced cooperation are obvious: it could avoid a timeconsuming reform of the Treaties. It could also demonstrate the maturity of the current constitutional architecture of the Treaties, since it is an instrument governed by the current fundamental charter of the EU, without the necessity of finding a solution to the European debt crisis out of the present system.

Finally, enhanced cooperation would not lead to an irreducible «rupture» with the UK or with other Member States, which could decide to join the enterprise at a later date, whereas such a reunion would be much more complicated in the case of a «pure» international agreement (33).

This path was suggested by some leading scholars as the way to overcome many of the EU's difficulties (34). Still today if one takes a closer look at the draft of the TSCG it is possible to see that the use of enhanced cooperation techniques is repeatedly advocated therein. Enhanced cooperation still remains a valid option, yet its use is encouraged in a text which is formally out of the EU Treaties' armoury. This Treaty is divided into six parts: Purpose and Scope (art. 1), Consistency and Relationship with Law of the Union (art. 2), Fiscal Compact (art. 3-8), Economic Policy Coordination and Convergence (art. 9-11), Governance of the Euro Area (art. 12-13), General and Final Provisions (art. 14-16).

From a constitutional law viewpoint, the most important clauses are represented by art. 1 (devoted to the aim of the Treaty, namely «to strengthen the economic pillar of the economic and monetary Union by adopting a set of rules intended to foster budgetary discipline through a fiscal compact, to strengthen the coordination of economic policies and to improve the governance of the euro area, thereby supporting the achievement of the European Union's objectives for sustainable growth, employment, competitiveness and social cohesion»), art. 2- concerning the relationship with EU law and reaffirming the precedence of EU law over the Treaty, a point which is present in many other parts of the Treaty - art. 3.2 - providing for the necessity for the States to codify the budget rule in national law «through provisions of bind-

(32) For instance see The Spinelli Group - Bertelsmann Stiftung (2013); CenTRE FOR STUdies ON Federalism (2011).

(33) It is interesting to note the content of art. 15 TSCG: «This Treaty shall be open to accession by Member States of the European Union other than the Contracting Parties. Accession shall be effective upon the deposit of the instruments of accession with the Depositary, who shall notify the other Contracting Parties thereof». Such openness differs from the model followed within the frame of an enhanced cooperation since it follows a pure public international law logic.

(34) PIRIS (2011). 
ing force and permanent character, preferably constitutional, or otherwise guaranteed to be fully respected and adhered to». It is debatable whether this last provision (art. 3.2) is inconsistent with art. 4.2 of the TEU stating the necessity to respect the national identity and constitutional structure of the EU Member States. Things are even more complex in countries whose fundamental laws are written in more than one document (see Sweden, for instance).

Another reference to EU law is included in art. 5 which requires contracting parties subject to an excessive deficit procedure to put in place «a budgetary and economic partnership programme including a detailed description of the structural reforms» to reduce the deficit. «The content and format of such programmes shall be defined in European Union law» (35).

Another problematic provision is art. 8, which gives the CJEU the jurisdiction to rule on the parties' compliance with the requirements of art. 3.2 of the Treaty. Is this provision compatible with the TFEU? The Preamble of the international agreement refers to art. 273 TFEU and art. 260 TFEU, but art. 273 TFEU seems to be very clear in anchoring the jurisdiction of the CJEU to the subject matter of the EU Treaties (36). As the Court said, the extension of the competences of the Court is possible always provided that the core of the Treaties (37) is respected. This point, again, led the commentators to take into account the very finality of this new international agreement in order to assess its compatibility with the EU Treaties.

As it is clear from the wording of these articles, the TSCG aims at getting a certain degree of bindingness, which was missing in the previous instruments of the European economic governance. This also explains the concern for the role to be played by the political institutions in the new contexts. The debate about the alleged loss of power of the European Parliament is emblematic from this point of view: it might look paradoxical that now many scholars have started worrying about the role of the European Parliament in the economy of this new Treaty since its position is relatively stronger than it

(35) Art. 5 TSCG.

(36) «Professor Craig, for instance, agreed that article 273 was sufficient to give the Court jurisdiction, but that article 8 of the proposed treaty caused difficulties because even though the Commission would not bring a case in name, the provisions meant that it might do so in effect, and there is no provision under the EU treaties for the Commission to bring such a case», House OF LORDS (2012).

(37) On the involvement of EU's institutions outside the scope of EU law see Case C-316/91 EP v Council and C-181/91, ECR 1994 p. I-625. On the possibility of giving the CJEU a jurisdiction not referred to in the Treaties see Opinion 1/00 [2002] ECR I-3493. On this see PeErs (2012b). 
was in the past, especially if one compares the position of this institution in the TSCG to that it had in the previous Stability and Growth Pacts.

This sounds as a paradox but is not a paradox at all, since it may be explained by the new binding nature of the TSCG. Indeed, according to Fasone: «Without doubt the EP is stronger now than it was at the time of the previous regime of the Stability and Growth Pact (1997 and reformed in 2005), when the name of this institution was not even mentioned in Regulations 1466/97 and 1467/97. However, at that time, the weak enforcement of the Stability and Growth Pack did not make the lack of involvement on the part of the EP particularly problematical. On the contrary, nowadays, in principle, the mechanism does not admit derogations, except for exceptional circumstances: compared to the past, warnings and sanctions have become semiautomatic because the system is based upon the reverse qualified-majority voting (warnings and sanctions proposed by the Commission are deemed to be adopted unless the qualified-majority in the Council rejects it). Furthermore, the co-ordination of economic policy has also become binding by the embedding the European Semester within the EU legislation» (38).

In order to find the exact «place» of EU institutions in the TSCG, it would be necessary to clarify the exact «scope» of this new international agreement and here again scholars are divided.

According to Peers (and to a certain extent Craig), the new international agreement would add «very little to the measures already set out in EU law or which have been or could be proposed as part of EU law» (39). A confirmation of this can be found even in the words pronounced at the end of 2011 by Guy Verhofstadt: «it is for political, symbolic reasons that they want to do this agreement» (40). On the other hand, as the UK Minister for Europe said: «there is no provision in the European Union treaties to make a balanced budget rule binding in a Member State's national law or subject to the jurisdiction of the European Court of Justice. There is no provision in the existing treaties for an automatic correction mechanism where a Member State deviates from that balanced budget path»(41). Moreover, those who argue that this international

(38) FASONE (2012).

(39) «There was general agreement with Professor Peers» view of the legal aspect, and our witnesses highlighted the ways in which provisions in the proposed Treaty were effectively mirrored in existing EU Treaty and legislative obligations. It is worth considering further whether there is any significant element of the treaty which is not or could not be achieved within the existing legal framework, not least for its relevance to the ease with which the proposed treaty might in due course be integrated into the EU legal framework, as proposed in article 16», HOUSE OF LORDS (2012).

(40) Mahony (2011).

(41) House of LoRds (2012). 
agreement would add something new, tend to recall that this Treaty would confer new powers on some EU institutions, in primis the Commission(42). Going to the last provisions of the TSCG, art. 16 seems to favour the future incorporation of the TSCG in EU law and this element makes the possibility of a future amendment of the EU Treaties still relevant while another crucial aspect is represented by the abandonment of the unanimity rule for the entry into force of the TSCG(43) under its art. 14: this is an important novelty that, according to many (44), should be transplanted in the EU law context.

\section{The New ECONOMic Governance: AsYmmetry AND INTERgOVERN- MENTALISM}

As said, looking at the new economic governance through the perspective of the TSCG scholars, there are two important factors of constitutional mutation: the increased asymmetry of the picture and an increase of intergovernmental dynamics.

The use of enhanced cooperation in the field of divorce and patents (45) and the current debate on the possibility of using the same mechanism for the introduction of a financial transaction tax (46), on the one hand, and the adoption of the new Treaty on Stability, Coordination and Governance in the Economic and Monetary Union (TSCG), on the other, have been giving new blood to the debate on asymmetry in the life of the Union.

Within the new European economic governance the asymmetric dimension of the EU has been amplified due to two main factors: First of all, some of the measures mentioned at the beginning have been adopted out of the EU law frame, namely via the conclusion of international agreements. This choice has permitted the creation of a set of rules shared by a group of the EU Member

(42) «Two points to make about this: First, there is room for disagreement as to whether particular provisions of this Draft Treaty confer «new» functions on the Commission. However, in my view there are aspects of, for example, articles 7 and 8 that in substance confer new powers on the Commission. Second, I reiterate the point that I made when I gave evidence: the mere fact that the Commission does have certain powers already under the Lisbon Treaty and legislation made thereunder does not in itself render lawful or legitimate the use of analogous powers outside the confines of the LT» (CRAIG, 2012b).

(43) Closa Montero (2011).

(44) See for instance the option in: The Spinelli Group- Bertelsmann Stiftung (2013).

(45) Council Decision of July 12th, 2010 (2010/405/EU), OJEU, L 189/12 and Council Decision of March 10th, 2011 (2011/167/ EU), OJEU, L 76/53. PeErs (2010).

(46) Proposal for a Council Directive-implementing enhanced cooperation in the area of financial transaction tax COM(2013) 71 final - 2013/0045 (CNS). See: FABBRINI (2013b). 
States in the form of a public international law treaty. The second reason regards the discipline of the enhanced cooperation mechanism in the TSCG. Concerning the first factor, as Bruno de Witte has pointed out, this «turn to international treaties» is not new; even in other cases this path has been followed (47).

The first reaction to this trend may be to interpret it as a return to intergovernmentalism and as a loss in terms of supranationalism. But, as Fabbrini has shown, the use of differentiated agreements among members of a union is known even in federal experiences (48).

Although this is not the first time in which the international law instruments have been employed to face a supranational issue scholars do not see a common strategy behind this trend, rather this path was allegedly chosen because of the flexibility it can offer (49). Against this background, the TSCG is peculiar for many reasons, the most evident being the fact that the TSCG intervenes in a situation already dominated by asymmetry, adding another pattern of differentiation. For instance, besides the already existing asymmetry between Euro and non-Euro members, this second group will be differentiated, from now on, between those who signed the new Treaty and those who did not. For instance, building on Rossi's work (50), it is possible to argue that the TSCG has created a system characterised by various concentric circles:

A first circle is represented by those EU Member States of the Eurozone that have ratified the TSCG [at least «twelve Contracting Parties whose currency is the euro» according to art. $14 \mathrm{TSCG}(51)]$.

(47) «In fact, there are numerous earlier examples of international treaties concluded between groups of Member States of the EU. They have concluded, ever since the 1950's, agreements in areas such as tax law, environmental protection, defence, culture and education», DE WiTTE (2013).

(48) «As the comparative analysis makes clear, also the US Constitution is endowed with an instrument - the «compact clause» - which allows states to pursue flexible and differentiated action within the American Union», FABBRINI (2012).

(49) «'Separate international agreements, which do not involve an amendment of the TEU and TFEU, can define alternative requirements for their entry into force. Not only can such agreements be concluded between less than all the EU states, but they can also provide for their entry into force even if not all the signatories are able to ratify. The Fiscal Compact offers a spectacular example of this flexibility in that it provided that the treaty would enter into force if ratified by merely 12 of the 25 signatory states, provided that those 12 are all part of the euro area. The fact that the authors of the Fiscal Compact moved decidedly away from the condition of universal ratification for its entry into force has created a 'ratification game' which is very different from that applying to amendment of the European treaties, where the rule of unanimous ratification gives a strong veto position to each individual country». DE WitTe (2013).

(50) Rossi (2012)

(51) Art. 14, p. 2: «This Treaty shall enter into force on 1 January 2013, provided that twelve Contracting Parties whose currency is the euro have deposited their instrument of 
A second group is given by those States that do not belong to the Eurozone but that have ratified the TSCG(52).

A third circle includes those States that do not participate in the Euro Plus Pact but that have ratified the TSCG(53).

It is clear from this scenario that the TSCG is going to amplify the variable-geometry Union, emphasising the asymmetric feature of the EU economic governance.

Indeed, another source of asymmetry in the new European economic governance is represented by the provisions included in the TSCG and devoted to the enhanced cooperation mechanism, namely art. 10 TSCG. Elsewhere(54) I expressed some doubts when comparing the wording of this provision with those of art. 20 of the TEU and art. 326 to 334 of TFEU, since art. 20 TEU describes enhanced cooperation as a «last resort» (55) while outside EU Treaties enhanced cooperation may be used when «necessary and appropriate». These formulas employed by the TSCG seem to introduce an element of discretion which seems to be very far away from the idea of $e x$ trema ratio.

The wording of art. 10 TSCG seems to show the hybrid nature of the Treaty itself. Even though it is an international agreement outside the scope of the EU Treaties, it is not completely outside the scope of the EU framework, as it aims to benefit from EU institutions and EU law features It can be said - and, perhaps, this was the intention of the drafters - that art. 10 TSCG might be, in principle, the pathway for the «communitarisation» of the TSCG required by art. 16 of the TSCG (56), through enhanced cooperation schemes

ratification, or on the first day of the month following the deposit of the twelfth instrument of ratification by a Contracting Party whose currency is the euro, whichever is the earlier». The ratification process can be followed at the following link: http://www.consilium.europa.eu/ policies/agreements/search-the-agreements-database?command=details\&lang=en\&aid=2012 $008 \&$ doclang $=\mathrm{EN}$

(52) For instance Poland

(53) For instance Hungary.

(54) Cantore - Martinico (2013).

(55) Art. 20 par. 2: «The decision authorising enhanced cooperation shall be adopted by the Council as a last resort, when it has established that the objectives of such cooperation cannot be attained within a reasonable period by the Union as a whole, and provided that at least nine Member States participate in it. The Council shall act in accordance with the procedure laid down in article 329 of the Treaty on the Functioning of the European Union».

(56) «Within five years, at most, of the date of entry into force of this Treaty, on the basis of an assessment of the experience with its implementation, the necessary steps shall be taken, in accordance with the Treaty on the European Union and the Treaty on the Functioning of the European Union, with the aim of incorporating the substance of this Treaty into the legal framework of the European Union». 
but this was also an option not exploited by the EU Member States even before the conclusion of the TSCG. There is another reason for which the text of art. 10 is at odds with its correspondent provisions included in the fundamental EU Treaties: art. 10 TSCG only states that enhanced cooperation may not undermine internal markets but internal market is just one of the elements included in art. 326 TFEU(57).

As said one of the causes of the increased asymmetry of the new European economic governance is given by the use of public international law instruments and this leads me to the other important factors of constitutional mutation introduced by the last legal developments. It concerns the EU's methodology of action or, in other words, the choice of the legal sources used to deal with the crisis. This point has been made by Chiti and Texeira (58) in a pretty clear way: according to them, when reacting to the crisis the EU has been progressively abandoning the Union method, minimising the role of the «Community channels» reinforcing the «intergovernmental instruments» (59). This has created a partial development of this discipline outside the EU Treaties which has resulted in a mix of EU legal acts and international Treaties with consequent issues in terms of consistency of some of the solutions adopted in this phase with EU law (60). For all these reasons the debt and financial crisis would have triggered a dangerous process of transformation with a «departure from the traditional paradigm of the EU economic constitution» (61) and the exhaustion of «the main democratic

(57) Art. 326 TFEU: «Any enhanced cooperation shall comply with the Treaties and Union law. Such cooperation shall not undermine the internal market or economic, social and territorial cohesion. It shall not constitute a barrier to or discrimination in trade between Member States, nor shall it distort competition between them». One could say that art. 10 in any case refers to all the relevant norms disciplining the phenomenon in EU law and this is true but why recall in an expressed manner just one of these elements? I see two possible interpretations here: the last lines of art. 10 could be either pleonastic (by expressing just one of the elements recalled by the relevant EU Treaties provisions) or maybe «selective», willing to give a particular value just to one of the elements recalled by the EU Treaties and thus creating something different. This problematic picture is made even more complicated by the unclear mandate of the CJEU (it is not clear from art. 8 TSCG whether the mandate of the Court concerns the content of art. 3 only or all the contents of the TSCG) and this of course matters i.e. one of the most important actors in the process of EU integration, the guardian of those constitutional safeguards that inspire the life of the Union. On the CJEU in this Treaty see: Ferreres Comella (2013), p. 236.

(58) Chiti -TeiXeira (2013).

(59) Chiti -TeiXeira (2013), p. 685.

(60) Bianco (2012).

(61) Chiti -TeiXeira (2013), p. 700. 
legitimacy sources of the EU polity» (62). The apex of this process has been undoubtedly represented by the TSCG.

Indeed, many other authors have argued that the latest developments affect the legitimacy and democracy of the European project and represent a fracture in the history of its economic constitution(63) and, more in general, a change in its constitutional paradigm: this is the point made by Dawson and de Witte, for instance, who argued that the anti-crisis measures have «altered the constitutional balance upon which the Union's stability is premised» (64), its commitment to pluralism and shows its inability to «accommodate the plurality of interests that distributive conflicts engender»(65). In their view, the crisis would cause the abandonment of the «relative neutrality of the Union's policies» (66) due to the necessity to face the crisis through the adoption of an austerity path, resulting also in a breach of the system of competences. Moreover, this situation is worsened by the absence of a political arena where parliaments and citizens can participate in and discuss (67)

(62) Chiti-Teixeira, (2013), p. 706.

(63) See also Joerges (2012).

(64) Dawson-de Witte (2013). This idea of constitutional balance is based on three components, namely the substantive, institutional and spatial dimensions, all these three would be affected by the recent evolution of the anti-crisis discipline: «The response to the euro-crisis destabilises the Union's substantive balance by circumventing its limited mandate in redistributive policies, which was meant to ensure that citizens have ownership and authorship over the core values that shape their society (the second section). It equally recalibrates the institutional balance by decreasing the voice of marginalised interests and representative institutions. This loss of representative influence is likely to result in greater power for national executives, with responsibilities for the initiation of, and compliance with, policy proposals shifting during the crisis towards the European Council (in the third section). Finally... the Union's response to the euro-crisis also threatens the spatial balance of the Union, which protects the voice of smaller and poorer Member States and their citizens from majoritarian or even hegemonic tendencies. The increased influence of the bigger, more resourceful Member States, in combination with the changes to the Union's substantive and institutional structure, leads to the loss of political autonomy for smaller and poorer Member States» DAwSON- DE WitTe (2013), pp. 817-818.

(65) DaWson- De Witte (2013), p. 822.

(66) Dawson- DE WitTe (2013), p. 823. «Until the advent of the euro-crisis, direct legislative influence in distributive policies was both legally and politically off-limits for the Union institutions. The Lisbon strategy and Europe 2020 agenda, for example, deliberately leave substantive choices to national political systems while attempting convergence of outcomes through benchmarking and intense transnational political cooperation. The eurocrisis changed this paradigm.» DaWson-DE WitTe (2013), p. 824. See also, ScharpF (2010); ScharpF (2009); SomeK (2011); Chalmers (2012).

(67) «In side-lining the national parliaments, the Union's response to the crisis has excluded a wide range of (often weak and diffuse) societal interests that have no presence in the transnational political arena» DAWsON-DE WitTE, p. 827. 
transnational political choices. The second element is given by the reduced role of the Commission and the European Parliament in the progressive «executivism» of the EU politics (68) in favour of the European Council(69).

Although it is difficult not to agree with these considerations, for the purpose of this work it is useful to recall what other scholarships have argued about the concrete impact of these measures on some key actors at national level, in primis national parliaments in order to give a more complete account of the debate. In the next section I will look at the level of national implementation of the supranational measures: as we will see, the attention at the State-level will offer counter-intuitive arguments. The attention paid to the national level is also consistent with the idea of European constitution presented at the beginning of the work, i.e. process fed by the interaction between constitutional levels or poles.

\section{What Can we Learn From the National LeVel?}

Even before the entry into force of art. 3 of the TSCG many national systems amended the financial section of their constitution or implemented the supranational obligations via super-primary norms. This process has of course gathered the attention of many constitutional lawyers (70), especially in Spain where the constitutional amendment was passed very quickly, with an evident sacrifice of the role of the parliament. Indeed the role of national parliaments in the procedures followed for the amendment was in some cases minimal and this was perceived as a reflection of the intergovernmental turn present at supranational level. In other words, both the incredible pressures

(68) On this process see: CURTIN (2009).

(69) On this see: Puetter, (2012). Finally, the creation of parallel institutions and the legal developments out of the EU Treaties also affected the institutional balance of the EU, the authors have the ESM in mind, since «voting under the ESM is based on capital contributions. Levels of influence upon the ESM's principle decisions are therefore determined by the financial strength of the Member States, only indirectly taking into account their populations. As a result, there are significant disparities in influence when compared to normal decisionmaking procedures. Germany, for example, has 27 per cent of all votes in the governing board of the ESM compared to 8.5 per cent of all votes in the Council. Cyprus by contrast carries 0.2 per cent of ESM votes compared to 1.2 per cent of votes in the Council. Most decisions of the ESM are to be made by an 80 per cent qualified majority (with only the most important decisions carried by unanimity)», DAwsON- DE WiTTE (2013), pp. 837-838.

(70) Fabbrini (2013a); Delledonne (2012); Pariente, (2010); Soulay (2010); Mathieu (2012); Häde (2010); Heinz (2010); MaYer (2011); LuCiani (2011); BranCasi (2012); Lupo (2011); De GraZia (2012); Ciolli (2012). 
to perform national reforms requested from the EU and the new arrangement of measures characterising the current economic governance created worries about the risk of isolating national parliaments from the heart of economic policies (71) in favour of national executives (72). This was also the concern behind the message e sent by the German Constitutional Court in the famous Greek bailout decision whereby it stated that: «the decision on revenue and expenditure of the public sector [must] remain in the hand of the German Bundestag as a fundamental part of the ability of a constitutional state to democratically shape itself. As elected representatives of the people, the Members of Parliament must remain in control of fundamental budget policy decisions in a system of intergovernmental governance as well»(73). This warning should be read together with the conclusion reached in the Lissabon Urteil(74) and in other decisions whereby the Bundesverfassungsgericht (BVG) emphasised the necessity to involve national parliaments in all the major decisions taken in the field of European Union affairs (75) and stressed the necessity to preserve their prerogatives. I shall come back to this point when dealing with the role of national courts.

Going to the impact of the supranational measures on the constitutional structures of Member States, authors like Lupo, Fasone and Griglio have noticed that the role of national Parliaments has not resulted necessarily diminished. This is a «counter-intuitive» (76) conclusion, since one could think that the intergovernmental nature of the last developments in this ambit result in affecting the centrality of national Parliaments (77). When looking at Spain and Italy, the executive has had a traditional prevalence in the design of the domain on the legislative design of fiscal policies and this element might lead to the conclusion of strengthening the role of this branch in the last period. However, the recent legislative developments have insisted, for instance,

(71) Rivosecchi (2012).

(72) Pitruzzella (2013).

(73) Judgment of the Second Senate of 7 September 2011-2 BvR 987/10- 2 BvR 1485/10-2 BvR 1099/10.

(74) BVerfG, 2 BvE $2 / 08$

(75) See 2 BvR 987/10, 2 BvR 1485/10, 2 BvR 1099/10; 2 BvE 8/11, 2 BVR 1390/12.

(76) Griglio - Lupo (2012), p. 340.

(77) «In other words, a further strengthening of the Executives is likely to happen and is actually happening, at least at a first stage: most of the national anti-crisis measures - either resulting from a spontaneous political decision of the national level, or to be considered as a due adaptation to European obligations - seem to find in the Government (rather than in the Parliament) their institutional point of reference», GRIGLIO - LUPO (2012), p. 333. 
on improving the parliamentary scrutiny in the budgetary process (78). This is in line with the trend suggested by recent comparative law analysis (79).

Other two elements that might limit the space of action of the executives are the recent introduction of the Fiscal Councils at national level(80) and the progressive de-nationalisation of the budget process as pointed out by Fasone and Griglio (81). In conclusion, a comparative study seems to demonstrate that the Europeanisation in this field has not necessarily affected the role of national parliaments, since they have improved their scrutiny powers or, at least, benefited (indirectly) from the less margins left to the executive due to the role acquired by actors such as the supranational actors (especially the Commission) and technical and independent bodies, such as the Fiscal Councils. In other words, national Parliaments seem to have window-opportunities offered by the European integration, despite the intergovernmental turn described before. Moreover, the TSCG gives another interesting arena (at least potentially) to them, namely art. 13(82). The main idea behind these provisions is that the European Parliament, unlike national counter-parts, was not designed to operate in isolation, but requires the cooperation of national parliaments to develop its role(83). As said, the same cooperative spirit inspires art. 13 that should be read in context with other articles of TSCG and the EU Treaties after the coming into force of the Lisbon Treaty, for instance with art. 4.2 TEU, other provisions included in the European Treaties (84) and its Protocols on the role of national parliaments and subsidiarity and proportionality. Perhaps this is why

(78) In Italy, the new Constitutional Law 1/2012 of 2012, has also improved the ex ante evaluation function of the Parliament.

(79) «One major trend is represented by the increasing interest of Parliaments for the ex ante evaluation of the fiscal frameworks and budgetary scenarios, which anticipates the drafting of the budget. A common feature characterising most national trends can be indeed identified in the fact that latest reforms and changes tend to extend Parliament's intervention working at the same time on the ex ante and ex post stage: their purpose is to strengthen the capacity of the Parliament to fully evaluate the budgetary provisions in the decision-making process and to influence the long-term planning; and to consider this transformation, in the medium-long term, as the first step towards the enforcement of the parliamentary scrutiny over budget execution « GRIGLIO - LuPO (2012), p 353.

(80) Directive 2011/85 and art. 3.2 of the TSCG.

(81) FASONE - Griglio, (2013), pp. 264-305.

(82) Art. 13: «As provided for in Title II of Protocol (No 1) on the role of national Parliaments in the European Union annexed to the European Union Treaties, the European Parliament and the national Parliaments of the Contracting Parties will together determine the organisation and promotion of a conference of representatives of the relevant committees of the European Parliament and representatives of the relevant committees of national Parliaments in order to discuss budgetary policies and other issues covered by this Treaty».

(83) ManZella (2008), pp. 333-334.

(84) See for instance art. 12 TEU. 
it has been said that «[m]aybe not formally speaking, but at least politically speaking, all National Parliaments have become, in a way, European Institutions» (85). This goes in continuity with the gradual introduction of national parliaments in the EU framework and has also been the result of the progressive dialectic between Constitutional courts [the German and Italian ones mostly (86)] and CJEU. Constitutional courts (the case law of the BVG is again emblematic) often conceive national parliaments as the «guardians of integration» and as a sort of indirect source of legitimacy for the EU.(87) However, if one has a closer look the Lisbon case one can realise that the idea of the BVG is quite clear in acknowledging that the European treaties contain important chances for national parliaments. Consequently national parliaments should do everything possible to implement them at their best and this proves that very much about their marginalisation depends on them, it is not only something unilaterally dictated by the supranational level. For all these reasons, as also Dawson and de Witte recognize, the TSCG «is a little better» (88) and seems to emerge in a more positive way from the jungle of sources characterising the new economic governance (89) with particular regard to the position given to national parliaments. Another topic that captured the interests of constitutional lawyers was that of the impact of EU measures on the relationship between centre and periphery, this happened especially in Spain and Italy but also in Germany (90). In this respect, it should be recalled that article 3 of the TSCG applies to both regional and local governments, as evidenced by the reference made by article 4 of the TSCG to Protocol number 12 , devoted to the procedure in the event of excessive deficit. Indeed, article 2 of Protocol number 12 clarifies that «government means general government that is central government, regional or local government and social security funds, to the exclusion of commercial operations, as defined in the European System of Integrated Economic Accounts.». In Italy, for instance after the constitutional reform, in light of the new art. 119, the system clearly limits the

(85) Van Rompuy (2012).

(86) See the Solange saga for instance: see e.g. Case BVerfGE 37, 2712 BvL 52/71 I-Beschluss Solange. See also the counter-limits doctrine of the Italian Constitutional Court: Decision No. 183 of 18 December 1973 and Decision No. 170 of 5 June 1984.

(87) See the criticisms made by the German Constitutional Court against its own parliament in the Lissabon Urteil, BVerfGE 123, 267, par. 411 of the judgment. also: BVerfG, 2 BVC 4/10 and BVerfG, 2 BVE 8/11 of 28 February 2012.

(88) «As a funding mechanism, however, the ESM is subject to almost non-existent parliamentary oversight both at the national and European levels. The Fiscal Compact is little better in this regard», DAWSON-DE WITTE (20I3), p. 833

(89) Contra Kocharov (2013).

(90) KöLling (2012); SchelLER (2013). 
possible recourse to borrowing for Regions and Local Authorities and, in addition, the Monti government established many cuts and some of these measures have also impacted on the regional structures(91). These are just a few examples showing the risk of centralization in the Italian system induced by the EU anti-crisis measures (92) and other similar examples come from Spain. However, as Ruiz Almendral pointed out, this centralization is only partly connected to what is happening at European level, as it has its roots in previous events (93). These observations ring true for Italy as well, where despite the bombast of federalism and constitutional reforms employed by all recent Italian governments, the crucial issue of «fiscal federalism» (94) has not been realized completely, more than 10 years after the constitutional reform of 2001 . This reveals a more complex mosaic, where the EU is just one piece of a broader set of factors to be taken into account. In conclusion, it seems true that the TSCG favors centralization and the erosion of regional autonomy, but its pressure is only a piece of a larger mosaic, where autonomy and place of Regions is also affected by other reasons which may lead back to policy decisions taken by States within their margins of appreciation. Another evidence of the fact that this centralization is imputable to each State and cannot be automatically traced back to the EU's intervention (95) is given by a recent Opinion of the Committee of Regions, where the Committee expresses «serious concerns

(91) The case of law decree 138/2011, then converted into law by Act number 148/2011 is emblematic. In fact, article 14 has reduced the number of members of Regional Councils (whose internal organization belongs to the exclusive legislative competence of Regions) and establishes incentives to induce Regions to make choices consistent with what is provided for in the decree (in this respect authors have talked of «financial blackmail.»).. MAzzolA (2012); FAlCon (2012). Groppi (2012). See also MAngiameli (2013). Indeed this provisions was declared unconstitutional by the Italian Constitutional Court in decision n. 198/2012.

(92). FALCON (2012).

(93). «The new stability rules may facilitate a re-centralization of the powers of the autonomous communities. This is in line with the ongoing centralization that the Fiscal Compact and more generally the European Union's economic constitution are bringing about.43 These instruments not only entail centralization of powers, but also the transformation of the member states' economic constitutions.», Ruiz Almendral (2013), p. 201. On Spain see also: Albertí Rovira (2013); Gordillo Pérez- Canedo Arrillaga (2013).

(94). See Scuto (2010) (discussing how this discipline is governed by law number 42/2009, which has been implemented through several legislative acts).

(95) Although Italian scholars have correctly emphasized the «inappropriate» contents of the letter sent by the ECB to the Italian government. In that letter the ECB wrote that:«There is a need for a strong commitment to abolish or consolidate some intermediary administrative layers (such as the provinces). Actions aimed at exploiting economies of scale in local public services should be strengthened». The text of the letter was also published by Il Corriere della Sera (http://www.corriere.it/economia/11_settembre_29/trichet_draghi_ inglese_304a5f1e-ea59-11e0-ae06-4da866778017.shtml): On this see Olivito (2014). 
about a contrary trend in some Member States in which the financial autonomy of local and regional authorities or the right to self-government at local level has been substantially curtailed» (96). Constitutional lawyers have also studied the implications of the EU crisis in terms of fundamental rights protections. I mentioned this point when recalling one of the factors of mutation in the constitutional balance of the EU according to Dawson and de Witte, namely the abandonment of the neutrality of policies of the EU during the crisis due to the need for a better coordination of national policies. The effort at better coordination of budgetary and financial national policies has had an impact sensitive welfare policy areas and this induced constitutional lawyers to wonder whether and how the austerity measures adopted have affected the protection of fundamental rights (mainly social and economic rights) guaranteed by the national constitutions. Part of the relevant scholarly contributions raised the issue, presenting it as potential threat to the national identity (97) of Member States, but the debate among constitutional lawyers has been characterised by a very abstract level, given also the broad wording of the relevant clauses since «social provisions in national constitutions are often worded in vague terms» (98). However this literal ambiguity rendered many of these conflicts business for courts and indeed in the last months judges have been protagonists of a certain number of very interesting decisions (99). As Fabbrini pointed out «courts have been mainly asked to rule on fiscal issues because the political branches have adopted reforms to the EMU architecture via international agreements, which - contrary to EU law - are amenable to domestic judicial review.»(100). Indeed courts, as frequently happened in the history of European integration, have been key in transforming these tensions between levels into fully-fledged conflicts, this is the case for instance of the recent decisions of the Portuguese Constitutional Court(101), or in sending a warning to guarantee the space of national parliaments (102). Sometimes they

(96) Opinion of the Committee of the Regions on «Devolution in the European Union and the place for local and regional self-government in EU policy making and delivery», (2013/C 139/08).

(97) Gambino- Nocito (2012); Ruggeri (2012); Spadaro (2011).

(98) O'CinNeIDE, (2013).

(99) Delledonne (2012).

(100) Fabbrini (2013c). See also: Fahey- Bardutzky (2013).

(101) Portuguese Constitutional Court, Acórdão $N^{\circ}$ 353/2012, judgment of 5 July 2012, and Acórdão $\mathrm{N}^{\circ}$ 187/2013, judgment of 5 April 2013, http://www.tribunalconstitucional.pt/tc/ home.html. On this see CisotTa - Gallo (2014).

(102) BVerfG, Case No. 2 BvR 987/10, judgment of 7 September 2011 Recker (2011); Schmidt (2013). See also: BVerfG, Case No. 2 BvR 1390/12 et al., judgment of 12 September 2012 . 
have also accepted a very tough compromise in terms of sovereignty for the sake of international stability [this is the Estonian case (103)], in other circumstances they have passed the ball to the CJEU [this is the case of the first preliminary ruling question raised by the Italian Constitutional Court within an incidenter proceeding (104) and of the reference sent by the Irish Supreme Court in the Pringle case(105)]. Partially different is the case of the recent referral raised by the German Constitutional Court to the CJEU and concerning the Decision of the Governing Council of the European Central Bank of 6 September 2012 on Technical Features of Outright Monetary Transactions (OMT) (106). As Gerstenberg wrote in this case «the deployment of the reference procedure is anything but an act of European-friendliness and judicial comity» (107). But can we really expect that Courts magically solve all these burning questions? Probably not and these difficulties may explain why the decision to the Pringle case of the CJEU has left many commentators unsatisfied (108). In conclusion, the present crisis (or crises as we saw at the beginning of this work) has amplified the asymmetric dimension of the European economic governance and the recourse to intergovernmentalism: indeed these two elements have been identified as the most evident example of the constitutional mutations produced by the need to challenge the crisis. However, we saw that these elements were present even earlier, in this respect perhaps the crisis has just increased their dose in the EU chemistry. Moreover, many of the issues that are now characterising the European project seem to be connected to the historical flaws of the economic integration (the weaknesses of the European economic architecture described at the beginning of this article). Here, once again, all the insufficiencies and cliché of the surpranational integration show up again, revealing the ancient roots of the crises suffered by the EU and the persistent stasis of the political actors which seem, once again, unable to domesticate the shortcomings of the crisis.

(103) Supreme Court of Estonia, Constitutional Case No. 3-4-1-6-12, judgment of 12 July 2012, http://www.nc.ee/?lang=en

(104) Italian Corte Costituzionale, ordinanza n. 207/2013, www.cortecostituzionale.it On this see: SAlazar (2013).

(105) Irish Supreme Court, Pringle v. The Gov't of Ireland, [2012] IESC 47

(106) Orders of 17 December 2013 and of 14 January 2014: 2 BvR 1390/12; 2 BvR 1421/12; 2 BvR 1438/12; 2 BvR 1439/12; 2 BvR 1440/12; 2 BvR 1824/12; 2 BvE 6/12.

(107) Gerstenberg (2014). See also Delledonne (20I4). See also Di Fabio Et. Al (2014),

(108) Case C-370/12, Pringle cit Tomkin (2013). 


\section{BiBLIOGRAPHY}

Albertí Rovira, E. (2013): «El impacto de la crisis financiera en el estate autonómico español», Revista Española de Derecho Constitucional, pp. 63-89.

Allemand, F. (2012): «La mutualisation des dettes souveraines: une perspective juridique», Revue du marche commun et de l'Union Européenne, pp. 635-641.

Armstrong, K. A. (2012): «Responding to the Economic Crisis: Public Law in a Post-Lisbon Age», http://eutopialaw.com/2012/02/21/responding-to-the-economic-crisis-public-lawin-a-post-lisbon-age/(last visited 1 November 2013).

Athanassiou, P. (2011): «Of Past Measures and Future Plans for Europe's Exit from the Sovereign Debt Crisis: What is Legally Possible (and What is Not)», European Law Review, pp. 558-575.

Balaguer Callejón, F. (2013): «Crisis Económica y Crisis Constitucional en Europa», Revista Española de Derecho Constitucional, pp. 91-107.

BARNIER, M. (2013): «L'union bancaire européenne, condition de la stabilité financière durable et prélude à une nouvelle étape de l'intégration européenne», Revue du marche commun et de l'Union Européenne, pp. 462-465.

Berkowitz, R. (2012) The Burden of our Times: the Intellectual Origins of the Global Financial Crisis, New York, NY, Fordham University Press.

Besselink, L.(2007): A composite European Constitution/Een Samengestelde Europese Constitutie, Groningen, Europa Law Publishing.

Besselink, L., ReEstman, J. H. (2011): «The euro crisis: storm, meet structure», European Constitutional Law Review, pp. 349-354.

Besselink, L., Reestman, J. H. (2012): «The Fiscal Compact and the European Constitutions: «Europe Speaking German», European Constitutional Law Review, pp. 1-7.

Beukers, T. (2013): «The Eurozone Crisis and the Legitimacy of differentiated Integration», DE Witte, B.; Heritier, A., Trechsel, A. (eds.) (2013), The Euro crisis and the state of European democracy: contributions from the 2012 EUDO dissemination conference, Florence, European University Institute, pp. 7-30.

Bianco, G. (2012): «The New Financial Stability Mechanisms and Their (Poor) Consistency with EU Law», EUI RSCAS 2012/44, http://cadmus.eui.eu/handle/1814/23428 (last visited 21 August 2013).

Bianco, G. (2013): «The Bitter End of Sovereign Debt Restructurings: The Abaclat v. Argentina Arbitration and the Eurozone Crisis», Legal Issues of Economic Integration, pp. 315-338.

Blot, C., Labondance, F. (2013): «Réformer la zone euro: un retour d'expérience», Revue du marche commun et de l'Union Européenne, pp. 140-147.

Bogdandy, A. von, Goldmann, M. (2013): «Die Restrukturierung von Staatsschulden als Ausübung internationaler öffentlicher Gewalt: zur Möglichkeit der inkrementellen Entwicklung eines Staateninsolvenzrechts», Zeitschrift für ausländisches öffentliches Recht und Völkerrecht, pp. 61-103.

Bonini, M. (2011): «Dai «Signori Dei Trattati» Al «Dominus Del Bilancio»: Principio Democratico, Meccanismo Europeo Di Stabilità E Forma Di Governo Parlamentare Nella Recente Giurisprudenza Del Bundesverfassungsgericht Tedesco», Rivista dell'Associazione Italiana dei Costituzionalisti, 4/2011, http://www.astrid.eu/Dossier--L4/Studi--ric/Bonini_AIC_4_2011.pdf (last visited 1 November 2013).

Borger, V. (2013): «How the Debt Crisis exposes the Development of Solidarity in the Euro Area», European Constitutional Law Review, 2013, pp. 7-36. 
Boudreau, M.A. (2012): «Restructuring Sovereign Debt under Local Law: are Retrofit Collective Action Clauses Expropriatory?», Harvard Business Law Review, pp. 164-186.

Bourrinet, J., Vigneron, P. (2013): «Les tribulations de la zone euro, péripéties d'une monnaie sans Etat», Revue du marche commun et de l'Union Européenne, pp. 525-536.

BRANCASI, A. (2012): «L'obbligo della copertura finanziaria tra la vecchia e la nuova versione dell'art. 81 Cost.», Giurisprudenza costituzionale, pp. 1685-1691.

Buckley, R.P. (2011): From Crisis to Crisis: the Global Financial System and Regulating Failure, Alphen aan den Rijn, Kluwer International.

Bugaric, B. (2013), «Europe Against the Left? On Legal Limits to Progressive Politics», LEQS Paper No. 61/2013, http://www.lse.ac.uk/europeanInstitute/LEQS/LEQSPaper61. pdf (last visited 1 November 2013).

Buiter, W., Rahbari, E. (2012): «The European Central Bank as Lender of Last Resort for Sovereigns in the Eurozone», The Journal of Common Market Studies Annual Review of the European Union in 2011, pp. 6-35.

Buzelay, A.(2009): «À propos de la crise américaine et de son impact sur la zone euro», Revue du Marché Commun et de l'Union Européenne, pp. 17-21.

BuZelay, A. (2013):«De l'union monétaire à l'union bancaire en Europe», Revue du marche commun et de l'Union Européenne, pp. 466-471.

Calliess, C. (2012): «The Future of the Eurozone and the Role of the German Constitutional Court», http://aei.pitt.edu/39286/1/researchpaper_5_2012_calliess_13.07.pdf (last visited 21 August 2013).

Cantore, C.M., Martinico, G. (2013): «Asymmetry or Dis-integration? A few considerations on the new «Treaty on Stability, Coordination and Governance in the Economic and Monetary Union», European Public Law, pp. 463-480.

Carcassonne, G. (2007): «La LOLF et le renouveau du contrôle, in Revue française de finances publiques», Revue française de finances publiques, pp. 77-85

Centre for Studies on Federalism (20Ii): «Appeal to European Leaders for the Euro and the European stability and development», http://csfederalismo.it/index.php/en/component/content/article/17-convegni/2317-appello-ai-leader-europei-per-un-euro-e-uneuropa-della-stabilita-e-dello-sviluppo (last visited 21 August 2013).

Chalmers, D. (2012): «The European Redistributive State and a European Law of Struggle», European Law Journal, pp. 667-693.

Chalmers, D. (2013), «Democratic Self-Government in Europe. Domestic Solutions to the EU Legitimacy Crisis», Policy Network Paper, www.policy-network.net/publications download.a. (last visited 1 November 2013).

Chaltiel, F. (2011): «Les crises de l'Europe», Revue de l'Union européenne, pp. 485-486.

Chemain, R. (2012): «Crise de l'euro: l'UEM contrainte de se réformer», Annuaire français de droit international, pp. 495-513.

Chiti, E., Teixeira, P. G. (2013): «The Constitutional Implications Of The European Responses to the Financial and Public Debt Crisis», Common Market Law Review, pp. 683-708.

Ciolli, I (2012): «Il pareggio di bilancio in Costituzione, tra le ragioni del diritto costituzionale e i vincoli comunitari», Il diritto dell'economia, pp. 105-112.

Cisotta, R., Gallo, D.(2014) «The Portuguese Constitutional Court case law on austerity measures: a reappraisal». LUISS Working Paper, No. 4/2014, http://eprints.luiss. it/1298/1/WPG_04-14_Cisotta_Gallo.pdf (last visited 26 April 2014). 
Claes, M. (2011): «The emergence of a European Constitution: European and national law in a European constitutional space», paper presented at the III EUNACON Workshop, University of Maastricht, 19-20 May 2011 (on file with author).

Clere, O., Kauffmann, P. (2012): «Vers la désunion monétaire européenne?», Revue du marche commun et de l'Union Européenne, pp. 642-650.

Closa Montero, C. (2011): «Moving Away from Unanimity: Ratification of the Treaty on Stability, Coordination and Governance in the Economic and Monetary Union», Recon Working Paper, 2011/38, http://www.academia.edu/1439935/Moving_Away_from_ Unanimity_Ratification_of_the_Treaty_on_Stability_Coordination_and_Governance_ in_the_Economic_and_Monetary_Union (last visited 1 November 2013).

Colliat, R. (2012): «A Critical Genealogy of European Macroeconomic Governance», European Law Journal, pp. 6-23.

Contiades, X. (ed.) (2013): Constitutions in the Global Financial Crisis: a Comparative Analysis, Farnham, Ashgate.

Cooper, G. (2008): The Origin of Financial Crises, New York, Vintage Books.

Courvoisier, C. (2012): «Crises de l'Europe, crise des symboles», Revue du marche commun et de l'Union Européenne, pp. 401-411.

Craig, P. (2012a): «The Stability, Coordination and Governance Treaty: Principle, Politics and Pragmatism», European Law Review, pp. 231-248.

Craig, P. (2012b): «Supplementary written evidence», in House of Lords, Select Committee on the European Union, The euro area crisis. Oral and written evidence, http://www. parliament.uk/documents/lords-committees/eu-select/euroareacrisis/Evidencevolume. pdf (last visited 1 November 2013).

Craig, P. (2013a): «Pringle: legal reasoning, text, purpose and teleology», Maastricht Journal of European and Comparative Law, pp. 3-11.

Craig, P. (2013b): «Pringle and Use of EU Institutions outside the EU Legal Framework: Foundations, Procedure and Substance», European Constitutional Law Review, pp. 263-284.

Curtin, D. (2009): Executive Power in the European Union. Law, Practices and the Living Constitution, Oxford, Oxford University Press.

Curzan, J. (2012): «A Critical Linkage: the Role of German Constitutional Law in the European Economic Crisis and the Future of the Eurozone», Fordham International Law Journal, pp. 1543-1587.

Dawson M., De Witte, F. (2013): «Constitutional Balance in the EU after the Euro-Crisis», Modern Law Review, pp. 817-844.

De Grazia, D. (2012): «L'introduzione del principio del pareggio di bilancio in Costituzione (tra vincoli europei e zelo del Legislatore)», Giurisprudenza Costituzionale, pp. 2483 2516.

De Witte, B. (2013): «Using International Law in the Euro Crisis Causes and Consequences», ARENA Working Paper, 4/2013, http://www.sv.uio.no/arena/english/research/publications/arena-publications/workingpapers/working-papers2013/wp4-13.pdf (last visited 21 August 2013).

De Witte, B., Beukers, T. (2013): «The Court of Justice approves the creation of the European Stability Mechanism: Pringle», Common Market Law Review, pp. 805-848.

De Witte, B., Heritier, A., Trechsel, A. (eds.) (2013): The Euro crisis and the state of European democracy: contributions from the 2012 EUDO dissemination conference, Florence, European University Institute. 
Degryse, C. (2012): «The new European economic governance», Working Paper European trade union institute 2012.14, http://www.etui.org/Publications2/Working-Papers/Thenew-European-economic-governance (last visited 1 November 2013).

Dehousse, R. (2012): «Le tre crisi del continente malato», Il Mulino, pp. 485-496.

Delledonne, G. (2014) «La «prima volta» di Karlsruhe: il rinvio pregiudiziale relative alle outright monetary transactions»,http://www.csfederalismo.it/attachments/2586_CommentoCSF25_Delledonne_Karlsruhe-OMT_130214.pdf (last visited 26 April 2014).

Delledonne, G. (2011): «Le procedure di bilancio tra equilibri delle forme di governo e ricerca della stabilità economica: una ricostruzione comparatistica delle esperienze francese e tedesca», Diritto Pubblico Comparato ed Europeo, pp. 469-491.

Delledonne, G. (2012): «Fiscal Constitution in the EU: From the Political to the Legal Constitution?», STALS Working Paper Archive, 5/2012, http://stals.sssup.it/files/Delledonne\%20Stals\%205\%202012.pdf (last visited 1 November 2013).

Delors, J. (2013): «JCMS 50th Anniversary Lecture: Economic Governance in the European Union: Past, Present and Future», Journal of Common Market Studies, pp. 169-178.

Di FABIo, U. ET AL. (2014), «Special Issue The OMT Decision of the German Federal Constitutional Court», German Law Journal (Special Issue), http://www.germanlawjournal.com/pdfs/TOC/Table_of_Contents.pdf (last visited 26 April 2014), pp. 107-382

DinAN, D. (2011): «Governance and Institutions: Implementing the Lisbon Treaty in the Shadow of the Euro Crisis», Journal of Common Market Studies, pp. 103-121.

Directorate General for Internal Policies Policy Department C: Citizens' Rights And Constitutional AfFairs (2012): «Challenges of multi-tier governance in the EU», Workshop 4 October 2012, http://www.europarl.europa.eu/document/activities/co nt/201210/20121003ATT52863/20121003ATT52863EN.pdf (last visited 1 November 2013).

Doely, P. (2013): «The European Central Bank's Securities Markets Programme: why a Necessary Response to the European Debt Crisis should come to an End», Minnesota Journal of International Law, pp. 214-246.

Draghi, M. (2012): «The future of the euro: stability through change», Die Zeit», 29 August 2012 and available at: http://www.ecb.europa.eu/press/key/date/2012/html/sp120829. en.html (last visited 1 November 2013).

FABBRINI, F. (2012): «The enhanced cooperation procedure: a study in multispeed integration», Centre for Studies on Federalism Research Paper, http://www.csfederalismo.it/attachments/2433_CSF-RP_Fabbrini_ENHANCED\%20COOPERATION_October2012. pdf (last visited 21 August 2013).

FabBrini F. (2013a): «The Fiscal Compact, the «Golden Rule' and the Paradox of European Federalism», Boston College International and Comparative Law Review, pp. 1-38.

Fabbrini, F. (2013b): «The Financial Transaction Tax: Legal And Political Challenges Towards A Euro-Zone Fiscal Capacity», Centre for Studies on Federalism Research Paper http://www.csfederalismo.it/attachments/2536_CSF-RP_FFabbrini_FTT_Oct2013.pdf (last visited 16 October 2013).

FabBrini, F. (2013c): «The Euro-Crisis and the Courts: Judicial Review and the Political Process in Comparative Perspective», http://papers.ssrn.com/sol3/papers.cfm?abstract_ $\mathrm{id}=2328060$ (last visited 1 November 2013).

Fahey, E., Bardutzky, B. (2013): «Judicial Review of Eurozone Law: The Adjudication of Postnational Norms in Eu Courts, Plural - A Casestudy of The European Stability Mechanism», http://papers.ssrn.com/sol3/papers.cfm?abstract_id=2287917 (last visited 1 November 2013). 
FALCON, G. (2012): «La crisi e l'ordinamento costituzionale», Le Regioni, pp. 9-20.

Fasone, C. (2012): «The Struggle of the European Parliament to Participate in the New Economic Governance», EUI Working Papers RSCAS 2012/45, Robert Schuman Centre For Advanced Studies EUDO European Union Democracy Observatory, http://cadmus. eui.eu/bitstream/handle/1814/23429/RSCAS_2012_45.pdf?sequence=1 (last visited 1 November 2013).

Fasone, C., Griglio, E. (2013): «Can Fiscal Councils Enhance The Role Of National Parliaments In The European Union? A Comparative Analysis», DE WitTe, B., Heritier, A., Trechsel, A. (eds.) (2013): The Euro crisis and the state of European democracy: contributions from the 2012 EUDO dissemination conference, Florence, European University Institute, pp. 264-305.

Ferran, E., Moloney, N., Hill, J.G., Coffee, J.C. (eds.) (2012): The Regulatory Aftermath of the Global Financial Crisis, Cambridge, Cambridge University Press.

Ferreres Comella, V. (2013): «Amending the National Constitutions to Save the Euro: Is This the Right Strategy?» Texas International Law Journal, pp. 223-240.

FINES, F. (2012): «Le TSCG dans la gouvernance économique européenne. Vers plus d'intégration budgétaire?», Revue du marche commun et de l'Union Européenne, pp. 651-656.

Gagliano, A. (2013): «The Introduction of the «Balanced Budget» Principle into the Italian Constitution: What Perspectives for the Financial Autonomy of Regional and Local Governments?», Perspectives on Federalism, E- 79-96.

Gambino, S., Nocito, W. (2012), «Crisi dello Stato, governo dell'economia e diritti fondamentali: note costituzionali alla luce della crisi finanziaria in atto», www.astrid-online (last visited 1 November 2013).

GAMPER, A. (2005): «A Global Theory of Federalism: The Nature and Challenges of a Federal State», German Law Journal, pp. 1297-1318.

Georgakopoulos, N. L. (2012): «Eurozone Bank Crisis \& Federalism», http://papers.ssrn. com/sol3/papers.cfm?abstract_id=2173263 (last visited 1 November 2013).

Gerstenberg, O. (2014), «An End to European Multilateralism: A Comment on the German Bundesverfassungsgericht's OMT decision», http://eutopialaw.com/2014/02/19/an-endto-european-multilateralism-a-comment-on-the-german-bundesverfassungsgerichtsomt-decision/(last visited 26 April 2014).

Giegerich, T. (2012): «The Federal Constitutional Court's Deference to and Boost for Parliament in Euro Crisis Management», German Yearbook of International Law, pp. 639657.

GINTER, C. (2013): «Constitutionality of the European Stability Mechanism in Estonia: Applying Proportionality to Sovereignty», European Constitutional law Review, pp. 335-354.

Giovanoli, M., Devos, D(eds.) (2010): International Monetary and Financial law: the Global Crisis, Oxford, Oxford University Press.

Goodhard, C.A.E. (2009): The Regulatory Response to the Financial Crisis, Cheltenham, Elgar.

Gordillo Pérez, L. I., Canedo Arrillaga, J. R. (2013): «La Constitución Económica De La Unión Europea. Bases De Un Modelo En Constante Evolución» Cuadernos de Derecho Transnacional, pp. 163-183.

Gordon, M. (20I4), «The United Kingdom and the Fiscal Compact: Past and Future», European Constitutional Law Review, pp. 28-53.

Griglio, E., Lupo, N. (2012): «Parliamentary democracy and the Eurozone crisis», Law and Economics Yearly Review, pp. 313-372. 
Grimaudo, P. (20I3), «Lo Stato sociale e la tutela dei diritti quesiti alla luce della crisi economica globale: il caso italiano», http://www.rivistaaic.it/sites/default/files/rivista/articoli/allegati/1_2014_Olivito.pdf (last visited 26 April 2014).

GrJebine, A. (2012): «Les Etats de la zone euro peuvent-ils se débarrasser de leurs dettes? », Revue du marche commun et de l'Union Européenne, pp. 657-663.

GroppI, T. (2012): «Editorial: The Impact of the Financial Crisis on the Italian Written Constitution», Italian Journal of Public Law, pp. 1-14.

Grozelier, A.M., Hacker, B., Kowalsky, W., Machnig, J., Meyer, H., Unger, B. (eds) (2013): Roadmap to a Social Europe, http://www.ictu.ie/download/pdf/roadmap_to_social_europe_sej_oct_2013.pdf (last visited 1 November 2013).

GuÉRot, U. (2012): «The euro debate in Germany: Towards political union?», European Council of Foreign Relations, http://ecfr.eu/page/-/GermanyReinvention.pdf (last visited 1 November 2013).

Habermas, J. (2012): The Crisis of the European Union: a Response, Cambridge, Polity.

HÄDE, U. (2010): «Die Ergebnisse der zweiten Stufe der Föderalismusreform», Archiv des öffentlichen Rechts, pp. 541-572.

Heinz, D. (2010): «Federal Reform II in Germany», Perspectives on Federalism, N.1-14.

Hinarejos, A. (2012): «The Euro Area Crisis and Constitutional Limits to Fiscal Integration», The Cambridge Yearbook of European Legal Studies, pp. 243-268.

Hoffmann, R.T. Krajewski, M. (2012): «Staatsschuldenkrisen im Euro-Raum und die Austeritätsprogramme von IWF und EU», Kritische Justiz, pp. 2-17.

Hofmeister, H. (2011): «To Bail Out or Not to Bail Out?: Legal Aspects of the Greek Crisis», The Cambridge Yearbook of European Legal Studies, pp. 113-134.

House of Commons European Scrutiny Committee (2012), «Treaty on Stability, Coordination and Governance: Impact on the Eurozone and the Rule of Law», http://www. publications.parliament.uk/pa/cm201012/cmselect/cmeuleg/1817/1817.pdf (last visited 1 November 2013).

House OF LORDS (2012): «The euro area crisis - European Union Committee», http://www. publications.parliament.uk/pa/ld201012/ldselect/ldeucom/260/26008.htm (last visited 21 August 2013).

IPSEN, H.P. (1972): Europäisches Gemeinschaftsrecht, Mohr Siebeck Verlag, Tübingen.

JAMET, J.F., KRUMBmüLLER, F. (2011): «La gouvernance économique de 1«Union européenne après la crise», Annuaire français de relations internationales, pp. 841-854.

JellineK, G. (1906): Verfassungsänderung und Verfassungswandlung, Haring, Berlin.

JoERGES, C. (2012): «Europe's Economic Constitution in Crisis and the Emergence of a new Constitutional Constellation «, Zentra Working Papers In Transnational Studies No. 06 /2012, http://papers.ssrn.com/sol3/papers.cfm?abstract_id=2179595 (last visited 1 November 2013).

KatsiKas, D. (2012): «The Never-Ending Greek Crisis: a Tragedy without a Catharsis», Revista de Estudios Europeos, pp. 33-52.

Kocharov A. (ed.), (2012): «Another Legal Monster? An EUI Debate on the Fiscal Compact», EUI Law Working Paper, 2012/09, http://cadmus.eui.eu/bitstream/handle/1814/21496/ LAW_2012_09_Kocharov_ed.pdf?sequence=1 (last visited 1 November 2013).

Kocharov, A. (2012): «The Fiscal Compact Treaty disempowers national parliaments and undermines trust between the peoples of Europe», http://blogs.lse.ac.uk/europpblog/2012/05/07/fiscal-compact-disempowers/ (last visited 1 November 2013).

Кокотт, J. (2013): «Perspectives on The Role of The Advocate General In The Eurozone Rescue Decision: Advocate General Kokott on Pringle V. Ireland», Michigan Journal of International law, pp. 1-13. 
KöLling, M. (2012): «Los límites de la deuda pública según la reforma de la Ley Fundamental alemana de 2009 «, Revista d'Estudis Autonomics i Federals, pp. 74-106.

Krugman, P. (2012): End This Depression Now! Norton and Company, London- New York.

Kube, H. (2012): «Nationale Budgethoheit und Europäische Integration», Archiv des oeffentlichen Rechts, pp. 205-222.

Kumm, M. (2005): «The jurisprudence of constitutional conflict: Constitutional supremacy in Europe before and after the Constitutional Treaty», European Law Journal, pp. 262307.

Lastra, R. M., Louis, J. V., (20I3): «European Economic and Monetary Union:History, Trends, and Prospects», Yearbook of European Law, pp. 57-206.

Leino, P., Salminen, J. (2013): «Should the Economic and Monetary Union Be Democratic After All? Some Reflections on the Current Crisis», German Law Journal, pp. 844-868.

Lienau, O. (2008): «Who is the «Sovereign» in Sovereign Debt?: Reinterpreting a Rule-ofLaw Framework from the Early Twentieth Century», Yale Journal of International Law, pp. 63-111.

LiNDSETH, P. (2012): «Greek 'Sovereignty' and European 'Democracy'-a bit of a walk-back, due to some 'colossal' concerns», http://eutopialaw.com/2012/02/15/greek-sovereigntyand-european-democracy-a-bit-of-a-walk-back-due-to-some-colossal-concerns/ (last visited 1 November 2013).

Loubert, A. (2012): «Sovereign Debt Threatens the Union: The Genesis of a Federation>», European Constitutional Law Review, pp. 442-455.

LouIs, J.-V. (2006): «The review of the stability and growth pact» Common market law review, pp. 85-106.

Louis, J.V. (2010): «Guest Editorial: The No-Bailout Clause And Rescue Packages», Common Market Law Review, pp. 971-986.

Louis, J.V. (2012): «The Unexpected Revision of the Lisbon Treaty and the Establishment of a European Stability Mechanism», Ashiagbor, D., Countouris N. and Lianos, I. (eds.), The European Union after the Treaty of Lisbon, Cambridge, Cambridge University Press, 2012, pp. 284-320.

LuCiani, M. (2011): «Unità nazionale e struttura economica. La prospettiva della Costituzione repubblicana», Diritto e società, pp. 635-719.

LuPo, N (2011); «Costituzione europea, pareggio di bilancio ed equità tra le generazioni. Notazioni sparse», www.amministrazioneincammino.it (last visited 1 November 2013).

MacCormick, N. (1993): «Beyond the sovereign state», Modern Law Review, pp. 1-18.

MaHONY, H. (2011): «Doubts increase over usefulness of new fiscal treaty», http://euobserver. com/843/114698. (last visited 21 August 2013).

Mangiameli, S. (2013): «Crisi economica e distribuzione territoriale del potere politico», Relazione al XXVIII Convegno annuale dell'AIC, www.associazionedeicostituzionalisti.it (last visited 1 November 2013).

Manzella, A. (2008): «I Parlamenti nazionali nella vita dell'Unione», Micossi, S., Tosato G.L. (eds.) L'Unione europea del XXI secolo - «Nel dubbio per l'Europa», Bologna, il Mulino, pp. 333-349.

Martinico, G. (2012): The Tangled Complexity of the EU Constitutional Process: The Frustrating Knot of Europe, Routledge, Abingdon.

MartucCI, F. (2012): «FESF, MESF et MES. La mise en place progressive d'un «pare-feu» pour la zone euro», Revue du marche commun et de l'Union Européenne, pp. 664-671. 
Mathieu, B. (2012): «Faut-il constitutionnaliser la règle de l'équilibre budgétaire ?» Revue française de finances publiques, pp. 165-167.

MAYER, C. (2011): «Greift die neue Schuldenbremse?», Archiv des öffentlichen Rechts, pp. 266-322.

Mazzola, G. (2012): «Le regioni fra riforme costituzionali, crisi finanziarie e federalismo», http://www.amministrazioneincammino.luiss.it/wp-content/uploads/2012/06/Mazzola_ Regioni_riforme-Cost_crisi_federalismo.pdf. (last visited 1 November 2013).

MenÉndez, A. J. (2013): «The Existential Crisis of the European Union», German Law Journal, pp. 453-526.

Messina, M. (2013): «La nuova governance economica e finanziaria dell'Unione: aspetti giuridici e possibili scenari per la sua integrazione nell'ordinamento giuridico UE», http://www.federalismi.it/ApplMostraDoc.cfm?content=La+nuova+governance+eco nomica+e+finanziaria+dell'Unione:+aspetti+giuridici+e+possibili+scenari+per+la+ sua+integrazione+nell' ordinamento+giuridico+UE+-+unione+europea+-+dottrina++\&artid=23575\#.Uo8NbNKKugQ (last visited 22 November 2013).

Miller, R. (2013): «Germany vs. Europe: The Principle of Democracy in German Constitutional Law and the Struggle for European Integration», Washington \& Lee Public Legal Studies Research Paper Series, 2013-14, http://papers.ssrn.com/sol3/papers. cfm?abstract_id=2309620 (last visited 1 November 2013).

Morrone, A. (2014), «Crisi economica e diritti. Appunti per lo stato costituzionale in Europa», Quaderni Costituzionali, pp. 79-108.

Notre Europe (2012) «Completing the Euro. A road map towards fiscal union in Europe. Report of the "Tommaso Padoa-Schioppa Group"», http://www.eng.notre-europe.eu/0113317-Completing-the-EuroA-road-map-towards-fiscal-union-in-Europe.html (last visited 1 November 2013).

O'Cinneide, C. (2013): «Austerity and the Faded Dream of a Social Europe», http://papers. ssrn.com/sol3/papers.cfm?abstract_id=2317534 (last visited 1 November 2013).

OfFe, C. (2013): «Europe Entrapped. Does the EU have the political capacity to overcome its current crisis?», European Law Journal, pp. 595-611.

Oliva E. (20I2): «La décision du Conseil constitutionnel du 9 août 2012», Revue française de droit administratif, pp. 1043-1057.

Olivares-Caminal, R. (et al.) (2011): Debt Restructuring, Oxford, Oxford University Press.

Olivito, E. (2014), «Crisi economico-finanziaria ed equilibri costituzionali. Qualche spunto a partire dalle lettera della BCE al governo italiano», http://www.rivistaaic.it/sites/default/files/rivista/articoli/allegati/1_2014_Olivito.pdf (last visited 26 April 2014).

Paliouras, V. (2011): «Why Europe Should Say No to the Proposed Framework of Economic Governance: A Legal and Policy Analysis in Light of the Establishment of the European Stability Mechanism and the Euro Plus Pact», http://papers.ssrn.com/sol3/papers. cfm?abstract_id=1908435 (last visited 1 November 2013).

PARIENTE, A. (2010): «L'équilibre budgétaire: un principe juridique insaisissable?», Revue française de finances publiques, pp. 163-185.

PeErs, S. (2012a): «The Stability Treaty: Permanent Austerity or Gesture Politics?» European Constitutional Law Review, p 404-441.

Peers, S. (2012b): «Written Evidence» House of Lords, Select Committee on the European Union, The euro area crisis. Oral and written evidence, London, House of Lords, http:// www.parliament.uk/documents/lords-committees/eu-select/euroareacrisis/Evidencevolume.pdf (last visited 21 August 2013). 
PeErs, S. (2010): «Divorce European Style: the First Authorization of Enhanced Cooperation», European Constitutional Law Review, pp. 339-358.

Pernice I. (2002): «Multilevel constitutionalism in the European Union», WHI Paper 5/02, http://www.rewi.hu-berlin.de/WHI/papers/whipapers502/constitutionalism.pdf (last visited 1 November 2013).

Pernice, I. (1998): «Constitutional Law Implications for a State Participating in a Process of Regional Integration. German Constitution and 'Multilevel Constitutionalism'», in RIEDEL, E.(ed) German Reports on Public Law. Resented to the XV International Congress on Comparative Law, Bristol 26 July to 1 August 1998, Baden-Baden, NOMOS, pp. 40-66, also available at: http://www.whi-berlin.eu/documents/pernice-regional-integration.pdf (last visited 1 November 2013).

Pernice, I. (1999): «Multilevel constitutionalism and the Treaty of Amsterdam: European constitution-making revisited?», Common Market Law Review, pp. 703-750.

Pernice, I., (2012): «International Agreement On A Reinforced Economic Union. Legal Opinion», http://www.greens-efa.eu/international-agreement-on-a-reinforced-economicunion-5125.html (last visited 1 November 2013).

Pinelli, C. (2013): «The Discourses on Post-National Governance and the Democratic Deficit Absent an EU Government», European Constitutional Law Review, 177-188.

PinON, S. (2013): «Crise économique européenne et crise institutionnelle à tous les étages», Revue du marche commun et de l'Union Européenne, pp. 218-230.

PIRIS, J. C. (2011): «It is Time for the Euro Area to Develop Further Closer Cooperation Among its Members», Jean Monnet Working Paper 5/2011 (http://centers.law.nyu.edu/ jeanmonnet/papers/11/110501.html (last visited 21 August 2013).

Pitruzzella, G. (2013): «Crisi economica e decisioni di governo», Relazione al XXVIII Convegno annuale dell'AIC, www.associazionedeicostituzionalisti.it (last visited 1 November 2013).

Poiares Maduro, M. (2012): «A New Governance for the European Union and the Euro: Democracy and Justice», RSCAS Working Paper 2012/11 [Florence: European University Institute] 2012, p. 32, https://papers.ssrn.com/sol3/papers.cfm?abstract_id=2180248 (last visited 21 August 2013).

Poiares Maduro, M., Kumm, M., De Witte, B. (2012): «The Euro Crisis and the Democratic Governance of the Euro: Legal and Political Issues of a Fiscal Crisis' Policy Report of the EUI Global Governance Programme, http://globalgovernanceprogramme.eui.eu/ wp-content/uploads/2012/06/Policy-Report10May20121.pdf (last visited 1 November 2013).

Poiares Maduro, M. (2003): «Contrapuntual law: Europe's constitutional pluralism in action» in Walker, Neil (ed.) Sovereignty in transition, Oxford: Hart, 2003, pp. 501-537.

Puetter, U. (2012): «Europe's Deliberative Intergovernmentalism: The new role of the Council and European Council in EU Economic Governance», Journal of European Public Policy, pp. 170-178.

Recker, S. (2011): «Casenote-Euro Rescue Package Case: The German Federal Constitutional Court Protects the Principle of Parliamentary Budget», German Law Journal, pp. 2071-2076.

Rivosecchi, G. (2012): «Il Parlamento di fronte alla crisi economico-finanziaria», Rivista dell'Associazione Italiana dei Costituzionalisti, 3/2012, http://www.rivistaaic.it/sites/ default/files/rivista/articoli/allegati/Rivosecchi-Il\%20Parlamento.pdf (last visited 1 November 2013). 
Rossi, L.S. (2012): «Fiscal Compact e conseguenze dell'integrazione differenziata nell'Ue», in Bonvicini G., Brugnoli, F. (eds.), Il Fiscal Compact, Edizioni Nuova Cultura, Roma, pp. 29-34.

Rossano, D. (20I4), «La crisi dell'eurozona e la (dis)unione bancaria», http://www.federalismi.it/federalismi/ApplMostraDoc.cfm?Artid=24607\&content=La+crisi+dell\%E2\% 80\%99Eurozona+e+la+(dis)unione+bancaria\&content_author=Diego+Rossano\#.U1ugP1V_tmg (last visited 26 April 2014).

Rousseau, D. (2010): «Déficit: «la Constitution n'a pas à définir le contenu des politiques publiques», interview «Le Monde» on 21 May 2010.

Rubio BARCEló, E. (2013): «Budget de la zone euro: trois fonctions, trois instruments», Revue du marche commun et de l'Union Européenne, pp. 214-217.

RufFerT, M. (2013) «Public law and the economy: A comparative view from the German perspective «, International Journal of Constitutional Law, pp. 925-939.

Ruffert, M. (2011): «The European Debt Crisis and European Union Law», Common Market Law Review, pp. 1777-1806.

RugGeri, A. (2012): «Crisi economica e crisi della Costituzione, in www.consultaonline.it. (last visited 1 November 2013).

Ruiz Almendral, V. (2013): «The Spanish Legal Framework for Curbing the Public Debt and the De囚cit», European Constitutional Law Review, pp. 189-204.

SAlazAR, C. (2013): «Crisi economica e diritti fondamentali», Relazione al XXVIII Convegno Annuale dell'AIC, www.associazionedeicostituzionalisti.it (last visited 1 November 2013).

Scharpf, F. (2009): «Legitimacy in the Multilevel European Polity» European Political Science Review, pp. 173-204.

SCHARPF, F. (2010): «The Asymmetry of European Integration, or:why the EU cannot be a "social market economy"», Socioeconomic Review, pp. 211-250.

Scheller, H. (2013) «Impacts of the Crisis on Fiscal Policy-Making in the Federal Republic», Cuadernos Fundacion Gimenez Abad, 5/2013, pp. 8-20, http://www.fundacionmgimenezabad.es/images/Documentos/Cuadernos/5_cuadernos_junio2013.pdf (last visited 1 November 2013).

Schmidt, S. (2013): «A Sense of Déjà Vu? The FCC's Preliminary European Stability Mechanism Verdict», German Law Journal, pp. 1-20.

SCIARRA, S. (2012): «Common places, new places The labour law rhetoric of the crisis», http://aei.pitt.edu/43376/1/20120628-040115_sciarra_n92-2012intpdf.pdf (last visited 1 November 2013).

SCIARRA, S. (2013): «Flessibilità e politiche attive del lavoro. Note critiche sulla riforma Monti-Fornero», Giornale di diritto del lavoro e di relazioni industriali, p-. 471-488.

Scuto, F. (2010): «The Italian Parliament Paves the Way to 'Fiscal Federalism'», Perspectives on Federalism, E-67-88.

Serricchio, F., Tsakatika, M., Quaglia, L. (2013): «Euroscepticism and the Global Financial Crisis», Journal of Common Market Studies, pp. 51-64.

Simonato, A. (2012), «Il Rapporto tra Regioni, Stato ed Ue alla Luce della crisi economica, dell'attualità Istituzionale, del dibattito sul paradigma della multilevel governance», http://www.federalismi.it/ApplMostraDoc.cfm?content=Il+rapporto+tra+Regioni, $+\mathrm{St}$ ato+ed+UE+alla+luce+della+crisi+economica,+dell\%E2\%80\%99attualit\%C3\%A0+ istituzionale,+del+dibattito+sul+paradigma+della+multilevel+governance+-+stato++dottrina+-+\&artid=22327\#.Um_4anC_USs (last visited 1 November 2013).

Skoutaris, N. (2012): « «The European Union's Uncommon Principle», Seminar at Durham University given on 6 December 2012 (on file with author). 
Soldatos, P. (2012): «Les données fondamentales de la crise dans la zone euro: essai explicatif d'une dérivé systématique multivariée», Revue de l'Union européenne, pp. 497-502.

SomeK, A. (2011): «The Social Question in a Transnational Context» LEQS Paper 37/2011, http://www.lse.ac.uk/europeanInstitute/LEQS/LEQSPaper39.pdf (last visited 1 November 2013).

Soulay, C (2010): «La 'règle d'or' des finances publiques en France et en Allemagne: convergence au-delà des différences?», Revue française de finances publiques, pp. 187-203.

Spadaro, A. (2011): «Diritti sociali di fronte alla crisi (necessità di un nuovo "modello sociale europeo»: più sobrio, solidale e sostenibile)», http://www.associazionedeicostituzionalisti.it/sites/default/files/rivista/articoli/allegati/Spadaro_0.pdf (last visited 1 November 2013).

TAJANI, A. (2012): «Crise financière et gouvernance économique européenne», Revue du droit de l'Union européenne, pp. 205-217.

the Hague ACademy of International LaW (2013): «The Legal Implications of Global Financial Crises: Selective Bibliography Les implications juridiques des crises financières de caractère mondial: bibliographie selective», http://www.peacepalacelibrary.nl/ wp-content/uploads/2013/08/The-Legal-Implications-of-Global-Financial-Crises-Bibliography.pdf (last visited 1 November 2013).

The Spinelli Group, Bertelsmann Stiftung (20I3): The Fundamental Law of the European Union, Gütersloh, Verlag Bertelsmann Stiftung.

Thym, D., Wendel, M. (2012): «Préserver le respect du droit dans la crise: la Cour de justice, le MES et le mythe du déclin de la Communauté de droit (arrêt Pringle)», Cahiers de droit européen, pp. 733-757.

Tirard, M. (2013): «L'intégration budgétaire croissante en Europe: entre théorie et réalité», Revue du marche commun et de l'Union Européenne, pp. 337-343.

Tomkin, J. (2013): «Contradiction, Circumvention and Conceptual Gymnastics: The Impact of the Adoption of the ESM Treaty on the State of European Democracy», German Law Journal, pp. 169-190.

Truger, A., Will, H. (2012): «The German 'debt brake' - a shining example for European fiscal policy?», Institute for International Political Economy Berlin, Working Paper, No. 15/2012, http://www.ipe-berlin.org/fileadmin/downloads/working_paper/ipe_working _ paper_15.pdf (last visited 1 November 2013).

Tsoukala, P. (2013), «Narratives of The European Crisis And The Future Of (Social) Europe», Georgetown Public Law and Legal Theory Research Paper No. 13-012, http:// scholarship.law.georgetown.edu/facpub/1180/ (last visited 1 November 2013).

Tuori, K. (2012): «The European Financial Crisis - Constitutional Aspects And Implications», EUI Working Papers LAW 2012/28, http://cadmus.eui.eu/handle/1814/24301 (last visited 1 November 2013).

Tusseau, G. (20I2), «La décision de la cour constitutionnelle fédérale allemande du 12 septembre 2012», Revue française de droit administratif, pp. 1058-1068.

VAn Rompuy, H. (2012), «Speech to the Interparliamentary Committee meeting on the European Semester for Economic Policy Coordination», Brussels, 27 February 2012,, http:// europa.eu/rapid/press-release_PRES-12-68_en.htm (last visited 1 November 2013).

Wallis, J.J., OAtes, W. (1998): «The Impact of the New Deal on American Federalism», in Bordo, M, Goldin, C.,

WeILER, J. H. H (2O I I): «The political and legal culture of European integration: An exploratory essay», International Journal of Constitutional law, pp. 678-694. 
White, E. (eds.): The Defining Moment: The Great Depression and The American Economy in the Twentieth Century, Chicago: Chicago University Press, pp. 155-180.

WiLKInson, M.A., (2013): «The Specter of Authoritarian Liberalism: Reflections on the Constitutional Crisis of the European Union», German Law Journal, pp. 527-560. 